\title{
FORMAL AMENDMENT RULES AND CONSTITUTIONAL ENDURANCE: THE STRANGE CASE OF THE COMMONWEALTH CARIBBEAN
}

Writing in the early 1960s about the wave of decolonisation that was occurring across the British Empire, the distinguished constitutional scholar, Kenneth Wheare, predicted that these former colonies, which had attained their independence by means of an Act of the imperial Parliament, would very quickly move to replace their independence constitutions with 'autochthonous' constitutions enacted by their own sovereign parliaments. This prediction has proved largely accurate in the case of many of Britain's former colonies, in Africa for example, which were replaced in their entirety almost before the ink was dry on the paper, but it has proved to be almost entirely inaccurate in the case of Britain's former colonies in the Commonwealth Caribbean. With the exception of Guyana and Trinidad and Tobago all of the remaining countries in the region retain the constitutions that were bestowed upon them by means of an Act of the British Parliament upon their independence. In some cases, for example Jamaica, the independence Constitution has endured for over 50 years, and Jamaica is followed closely by Barbados where the independence Constitution has endured for 49 years. The constitutions of these two countries have thus already exceeded the average lifespan for democratic constitutions, which is 42 years, 1 and there are others which will soon exceed this benchmark.2

Elkins et al have famously argued that one of the key factors in explaining a constitution's endurance is its flexibility; that is, the inclusion of formal amendment procedures which allow the constitution to adapt to meet changing political, social and economic circumstances. According to Elkins et al this flexibility is crucial to constitutional endurance because 'it offers an ongoing and inclusive alternative to wholesale replacement of the constitution,' thus helping to maintain the core elements of the constitutional bargain while all the time generating 'a vital constitutional politics.'3 Rigid constitutions, by contrast, because they do not allow for the readjustment of the constitutional bargain

\footnotetext{
1 Z Elkins, T Ginsburg, and J Melton, The Endurance of National Constitutions (Cambridge University Press, Cambridge, 2009) 32.

2 For example, The Bahamas, which gained independence in 1973.

3 Elkins et al, n1 above at 82
} 
from time to time are much less resilient and much more likely to be replaced in their entirety.4 While not wishing entirely to disavow this theory, I propose to show in this chapter that the longevity of the independence constitutions of the Commonwealth Caribbean does not fit comfortably within this account of constitutional endurance for at least two reasons.

The first is that the constitutions of a number of the eastern Caribbean islands are extremely rigid, and include some of the most onerous referendum requirements to be found anywhere in the Commonwealth. Yet, as I will demonstrate, they have proven to be no less resilient than the constitutions of neighbouring countries which are less rigid. Their endurance is all the more remarkable in view of the profound disconnect between the procedures that were followed at the time of their creation by the so-called constituent power, Britain, and the constraints that the constituent power placed on the constituted power in order to amend the constitution.5 The second reason is that even in those countries with relatively flexible constitutions, which permit constitutional amendment by means of a simple majority in a referendum or a special legislative majority, constitutional reform has still proved to be remarkably difficult to achieve. There have thus been relatively few amendments to these ostensibly flexible constitutions, and where they have occurred they have tended to be conservative, 'directed toward perfecting the system by preserving its essence intact.' 6

I propose, therefore, to offer an alternative explanation for constitutional endurance in the region, which sheds a different light on the rationale for the inclusion of formal amendment rules in the context of the decolonisation of the region, and which is informed by Ginsburg and Melton's theory of 'amendment culture.' 7 This involves recognising that within any constitutional system there is 'a borderline level of resistance to formal constitutional change,' which can 'vary

\footnotetext{
4 Ibid.

5 As discussed by Yaniv Roznai in chapter (?), 'The Spectrum of Constitutional Amendment Powers'. 6 P Sutton (1999), 'Democracy in the Commonwealth Caribbean', Democratization 6:1, 67-86, at 69.

7 T Ginsburg and J Melton, 'Does the Constitutional Amendment Rule Matter at All? Amendment Cultures and the Challenges of Measuring Amendment Difficulty, PUBLIC LAW AND LEGAL THEORY WORKING PAPER NO. 472.
} 
according to the political weight attached to the value of entrenchment.' 8 Amendment culture thus encompasses 'a set of attitudes about the desirability of constitutional amendment, which exists independently of the substantive issue under consideration.' 9 I will argue that this is a particularly helpful analytical tool in the context of the Commonwealth Caribbean because it suggests that there may be a contextual explanation for the failure of the region's governments to effect constitutional reform, which does not depend exclusively on the existence of particular institutional obstacles, and which, while subject to some local variation, also functions at a regional level. I intend, however, to go further than merely asserting the existence of such a culture by identifying the factors that have contributed to the emergence of such a culture across the region.

The paper is in two parts. In Part I, I will discuss the rationale for the inclusion of formal amendment rules in Commonwealth Caribbean constitutions, which had very little to do with promoting flexibility and everything to do with securing the survival of the region's political leaders in the post-independent state as well as, in some cases, preserving in perpetuity the system of government inherited from the former colonial power. In Part II, I will explore the impact of these formal amendment rules upon post-independence constitutional reform in the region and their interaction with the region's amendment culture. In conclusion I will argue that while the experience of the Commonwealth Caribbean may not invalidate Elkins at al's theory about constitutional design and the importance of flexibility it does demonstrate that a theory which is based on constitutional design alone is not sufficiently rich to capture the other forces that may contribute to constitutional endurance. Particularly for postcolonial societies, such as those in the Commonwealth Caribbean, it is necessary to take account of the experience of colonial rule and how this informed both the institutional structure for amending the constitution as well as attitudes towards constitutional amendment in the postcolonial era.

8 Ibid.

9 Ginsburg and Melton 15 above at 12. 


\section{PART I THE RATIONALE FOR THE INCLUSION OF FORMAL AMENDMENT RULES IN COMMONWEALTH CARIBBEAN CONSTITUTIONS}

Though there is some variation as between Commonwealth Caribbean constitutions in terms of the provisions that they entrench and the degree to which those provisions are entrenched, the two most common amendment rules to be found in these constitutions are special legislative majorities and referendum requirements. In most countries special legislative majorities are necessary, but not sufficient, to effect constitutional amendment since, regardless of the size of the special legislative majority, the amendment still needs to be a approved by a prescribed majority of citizens voting in a referendum.

\section{Special legislative majorities}

In some cases a special legislative majority involves no more than an absolute majority of all the members of the House, whether or not all the members of the House are present when the vote is taken.10 In most cases, however, the requirement is more demanding; involving a two-thirds or even a three-quarters parliamentary majority in order to approve a constitutional amendment, depending upon the importance of the constitutional provision to be amended. This majority can take different forms. In countries, such as Antigua, Belize and St Lucia, it is two-thirds or three-quarters of all the members of the House of Representatives only; thereby allowing the elected House to bypass the Senate, which is wholly nominated. 11 In those countries with unicameral parliaments, such as Dominica, Guyana and St Vincent, it is two-thirds of all the elected members; 12 thus again allowing the elected element to bypass the nominated element. In the Bahamas, Barbados, and Jamaica, however, it is two-thirds of all members of both Houses of Parliament.13 In Trinidad and Tobago too, for the

\footnotetext{
10 See, for example, s.49(4) Barbados and s.49(b) Jamaica.

11 s.47(2) Antigua, though the Senate can delay the Bill for one parliamentary session (s.55);

s.69(3) and (4) Belize; and s.41(3) to (5) St Lucia

12 s.42(2) Dominica; Article 164(2) Guyana and s.38(2) St Vincent.

13 Article 54(2) Bahamas; s.49(2) Barbados; s.49(40(a) Jamaica.
} 
more deeply entrenched provisions, it is a three-quarters majority of all members of the House of Representatives and a two thirds majority of all members of the Senate.14

The standard rationale for the inclusion of a procedure for amending any constitution is the need for constitutions to adapt to changes in society. Over an extended period of time a constitution may no longer adequately meet the needs of the society for which it was designed or may embody principles that have long since been rejected by that society.15 In such circumstances it will be necessary to have some means of amending the constitution. However, amendment rules that insist on special procedures, such as special legislative majorities, arguably detract from this objective by making the constitution more difficult to amend, and opens amendment rules to the criticism that they are counter-majoritarian and, therefore, undemocratic.16 This criticism is usually countered by two arguments. Firstly, that the broad consensus which is required to achieve a special legislative majority expands the class of persons whose interests are taken into account before a constitution can be amended, thereby making the process, arguably, even more democratic than that required for enacting ordinary legislation.17 Secondly, that because the support of the opposition is usually required to satisfy a special legislative majority such a provision creates 'a climate or environment of deliberation' about the content of the proposed amendment and forces those advocating the amendment to advance arguments 'based on general and abstract principle while avoiding narrow partisan or sectoral interests.'18 This should, in turn, ensure that the amendment becomes part of the constitution 'with a near conclusive presumption of legitimacy.'19

14 s.54(3) (i) and (ii) Trinidad and Tobago.

$15 \mathrm{R} \mathrm{Ku}$, Consensus of the Governed: The Legitimacy of Constitutional Change 64 Fordham Law Review 535 (1995), 542

16 CL Eisgruber, Constitutional Self-Government (Harvard University Press; Cambridge MA; 2001) 10-25

17 L G Sager, 'The Birth Logic of a Democratic Constitution', in (J Ferejohn et al, ed.s 2001) Constitutional Culture and Democratic Rule 131-133.

$18 \mathrm{~J} \mathrm{Ferejohn} \mathrm{and} \mathrm{L} \mathrm{Sager,} \mathrm{'Commitment} \mathrm{and} \mathrm{Constitutionalism'} \mathrm{University} \mathrm{of} \mathrm{Texas} \mathrm{Law} \mathrm{Review}$ (2003) 81: 1929-63 at 1957.

19 BP Denning and JR Vile, 'The Relevance of Constitutional Amendments: A Response to David Strauss' Tulane Law Review (2002) 77: 247-82. 
These may be compelling arguments for the inclusion of formal amendment rules, such as the requirement for a special legislative majority, but they were certainly not articulated at the time the region's independence constitutions were being drafted. Instead, the main reason for including a requirement for a special legislative majority, and thus making the constitution more difficult to amend, was to secure the survival of the region's political leaders in the postindependent state. Parkinson thus argues that in Jamaica, where the negotiations surrounding independence took place against the backdrop of an upcoming election, the result of which was uncertain, with the two main parties - the Peoples National Party and the Jamaica Labour Party - anxious about the rise of the minority Peoples Progressive Party, the two main parties sought to secure their dominance by making provision for a two-party system and enshrining the office of the Leader of the Opposition within the independence Constitution.20 This was then 'locked-in' by the inclusion of an entrenchment mechanism, which ensured that provisions, such as those establishing the Leader of the Opposition, could not be altered without a two-thirds majority of both Houses of Parliament.21 Far from being concerned to facilitate constitutional amendment in the future, or to deepen and enrich the debate that should precede constitutional amendment, the inclusion of a requirement for special legislative majorities was thus motivated primarily by considerations of realpolitick.

One of the foremost scholars of the new Commonwealth constitutions that emerged in the wave of decolonisation that took place in the late 1950s and early 1960s, S A de Smith, has also written of the level of distrust that existed amongst political leaders of Britain's former colonies who feared that they might be the losers in the independence stakes.22 In de Smith's view it was this distrust that led directly to the inclusion of rigid amendment procedures in these new Commonwealth constitutions:

[I]n drafting a new constitution for a new state it may be unrealistic to begin with presumptions in favour of brevity and flexibility. Often it will

\footnotetext{
20 C Parkinson, Bills of Rights and Decolonization: The Emergence of Domestic Human Rights Instruments in Britain's Overseas Territories (Oxford, UK; Oxford University Press; 2007) 21 s.49 Jamaica Constitution 22 A distinguished constitutional scholar and legal adviser to the British Government.
} 
be politically impossible to obtain general agreement on a new constitution unless it is both lengthy and rigid. Those who don't expect to find themselves in power on Independence Day may well be profoundly distrustful of the majority party and its leaders, and the price of their acquiescence in the new order is therefore likely to be a somewhat cumbersome constitutional machine with built-in resistances against subsequent modifications.23

The most rigid amendment procedures to be found in Commonwealth Caribbean constitutions are the referendum requirements, some of which are especially onerous, but, as well see below, their inclusion also owes much to the British Government's distrust of the region's independence leaders.

\section{Referendum requirements}

The constitutions of all but three countries in the region - Barbados, Trinidad and Tobago, and Belize - stipulate that various constitutional provisions require, in addition to the approval of a special legislative majority, the approval of a prescribed majority of citizens voting in a referendum before they can be amended. In the three countries that do not include a referendum requirement it was adjudged that this additional barrier to constitutional amendment was unnecessary. As the Wooding Commission, which a decade after independence had been charged with reviewing and recommending reforms to Trinidad and Tobago's independence Constitution, explained in response to a proposal to include a referendum requirement in the revised Constitution:

We disagree. In our view, a referendum is not a particularly accurate method of determining the state of public opinion on issues of constitutional reform. Under a system of party politics it is quite probable that many an answer given will not be an answer on the merits of the question asked, but will merely reflect loyalty to what is known to be the party's view, lest defeat of the party on the issue submitted should result 
in a consequences too undesirable to be permitted. Accordingly, we reject the idea of a referendum as the final prerequisite for amending the Constitution. 24

Everywhere else, however, provision was made for certain constitutional amendments to require the additional approval of voters in a referendum. In most cases a simple majority of the electors voting in the referendum is all that is needed.25 However, in three countries - Antigua,26 St Vincent and the Grenadines,27 and Grenada28 - approval by a two-thirds majority in a referendum is necessary.29 In the Federation of St Kitts and Nevis also, a two-thirds majority of the voters in Nevis is required in order for Nevis to secede from the Federation.30 To appreciate the rationale for the inclusion of such onerous referendum requirements it is necessary first to understand the decolonisation process in the eastern Caribbean and the extent to which this was informed by the British Government's fears of what might happen after independence.

\section{Constitution-making in the Eastern Caribbean}

Immediately prior to independence the islands of the eastern Caribbean Antigua and Barbuda, Dominica, Grenada, St Kitts and Nevis, St Lucia and St Vincent and the Grenadines - enjoyed 'Associated State' status under the West Indies Act 1967 (WIA 1967). As well as bestowing full internal self-government upon these countries, s.10 WIA 1967 made provision for the termination of their status as Associated States prior to independence. This differed depending upon whether it was the British Government or the Associated State that wished to terminate the association. In the first case, the association could be terminated

24 Report of the Constitution Commission of Trinidad and Tobago (January 22, 1974) pp.s 430 431. Available at <http://www.ttparliament.org/documents/1101.pdf>

25 The Bahamas, Dominica, Guyana, Jamaica, St Kitts and St Lucia.

$26 \mathrm{s.47(5)(c)}$

$27 \mathrm{s.38(30( \textrm {b } )}$

$28 \mathrm{~s} .39(5)(\mathrm{c})$

29 In St Kitts and Nevis, a two thirds majority of the electors in Nevis in a referendum is required if Nevis wishes to secede from the Federation of St Kitts and Nevis. s.113 Constitution.

30 In Jamaica too, a two-thirds or three-fifths majority may be required in a referendum, but this is only if the amendment has previously been rejected by the Senate. 
by a relatively straightforward procedure, which required only that the British Government give the Associated State concerned six months' notice of its intention to terminate the status of association, followed by an Order-in-Council of Her Majesty approved by a resolution of each House of the British Parliament.31 In the second case, a Bill providing for termination required the support of not less than two-thirds of all the elected members of the legislature of the Associated State and no less than two-thirds of the votes cast in a referendum.32 The WIA thus offered a mechanism through which the will of the people could be expressed by holding a referendum prior to termination of the association with Britain. Deciding which of the available routes to independence should be followed proved, however, to be a highly contentious matter in a number of the Associated States. This was because in many cases opposition groups, even if they supported independence in principle, wanted a referendum to be held prior to termination of the association, whereas the British Government preferred to proceed by a simple Order-in-Council.

One of the most notorious examples of disagreement between opposition groups and the British Government occurred in Grenada, which at the time was governed by the Grenada United Labour Party, led by Eric Gairy, who had once been memorably described in a Colonial Office briefing as 'a man who is almost too bad to be true'.33 Gairy had previously been excluded from Grenada's Legislative Council as a result of electoral malpractice during the 1957 elections, and in June 1962 had been dismissed from office as Chief Minister by the British Government as a result of a report of the Commission of Enquiry into the Control of Public Expenditure in Grenada. 34 Though Gairy was returned to office, following his party's victory in the 1967 elections, his authoritarian style of leadership had not changed, and in the years leading up to independence he

\footnotetext{
31 s.10(2) WIA 1967

32 s.10(1) WIA 1967. There would also have to be an interval of not less than 90 days between the introduction of the Bill and its second reading. 33 TNA: CO 1031/5218, Personality Notes for the Windwards Constitutional Talks, 18 April 1966. Quoted by S Mawby, Ordering Independence: The End of Empire in the Anglophone Caribbean, 1947-69 (Palgrave Macmillan, Hampshire, UK; 2012) 216

34 The report found that Gairy had been implicated in 'the deliberate and systematic violation of financial regulations, the browbeating of public servants' and 'the illegal purchase with public monies of luxury items'. For the full report see Parliamentary papers 1961-1962: Cmnd.1735.
} 
embarked on what Mawby has described as 'a policy of repression in which any challenges to his personal rule were interpreted as a threat to political order in Grenada.'35 It was during this period that Gairy established a special secret police force made up principally of ex-convicts,36 known locally as the 'Mongoose Gang'. Their role, which has been compared to that of Haiti's Tonton Macoutes, was to intimidate opposition groups, such as the emerging New Jewel Movement (NJM): a coalition of Marxists, Black Power activists and liberal reformists. NJM leaders were subject to brutal attacks by Gairy's Mongoose Gang, which left them with serious head injuries, broken jaws and teeth,37 and which culminated in the in the killing, in January 1974, of one of the leaders of the NJM, Rupert Bishop.38 Notwithstanding Gairy's appalling record of authoritarianism and of brutal political repression, the British Government was happy to terminate Grenada's status of association by means of a simple Order-in-Council, rather than accede to the opposition's request for a referendum to be held.

While it may have been the most notorious, Grenada was not the only example of an eastern Caribbean island where there was profound disagreement about whether or not a referendum should be held prior to the termination of association with Britain. In St Lucia, tensions between the governing and opposition parties over this issue were of such concern to the British Government that the possibility of having a Royal Navy Ship close at hand as a precautionary measure was actively considered 39 Nevertheless, the British Government was determined to proceed to independence without a referendum on the basis that:

Any attempt by the British Government to delay a decision on independence would be to go against the wishes of an elected Government with universal adult suffrage and be seen locally as support for the St Lucia opposition. This would cause dismay among other

\footnotetext{
35 Mawby n42 above, 215-222.

36 Ibid.

37 HC Deb 11 December 1973 vol 866 cc331-61

38 Rupert Bishop's son, Maurice Bishop, went on to lead the coup which eventually removed Gairy from power in 1978.

39 Report of St Lucia Constitutional Reform Commission 2011, p.62. Unpublished. On file with author.
} 
Commonwealth Caribbean Governments and could have a serious effect on the progress of the three remaining Associated States to independence.40

The essence of the British Government's thinking on the utility of referendums in this context is perfectly encapsulated in a report to the Minister of State for Foreign and Commonwealth Affairs in connection with the Dominican Government's request for independence. Responding to demands by opposition groups for a referendum to be held in Dominica prior to the termination of its association with the United Kingdom, the report's author summarily dismissed the suggestion on the basis that: 'It [a referendum] seemed to me a rather blunt instrument to use to decide complex constitutional issues.' 41 The author of the report was, instead, supportive of the Dominican Government's decision not to hold a referendum that would require the approval of a two-thirds majority of its citizens: 'Few governments would be confident of obtaining such a massive plurality on any public issue.' 42 In conclusion, the author of the report candidly admitted that:

The British Government's consistent policy [has] been to be guided by what seemed to British Ministers to be the wishes of the majority of the territory. I do not think that further evidence of popular opinion can reasonably be demanded.43

Notwithstanding the British Government's scepticism about the value of referendums as a measure of the expression of the will of the people, referendum requirements were included in the independence Constitutions of all six Associated States.

As Tierney argues, a referendum requirement may be justified in plural societies where they are necessary specifically to protect the interests of particular minorities and the consent of the specific minorities should be part of any

40 Ibid

41 Dominica, Termination of Association: A Report to the Minister of State for Foreign and Commonwealth Affairs by RN Posnett. Cmnd. 7279, paragraph 39.

42Ibid.

43 Ibid. 
legitimate consensus on the issue at hand.44 Such a justification did not, however, apply in the case of these Associated States, which were not in any sense plural societies. The inclusion of a referendum requirement in their case arose instead from the British Government's deep distrust of the region's independence leaders; especially Gairy in Grenada, Vere Bird in Antigua, and Ebenezer Joshua in St Vincent and the Grenadines, all of whom had fallen foul of the Colonial Office at different times on their country's journey to independence.45 It is thus no coincidence that the independence Constitutions of these three countries contain some of the most heavily entrenched constitutional provisions to be found anywhere in the Commonwealth, let alone the Caribbean, requiring twothirds approval in a referendum before they can be amended.46

Such onerous referendum requirements are self-evidently counter-majoritarian. They permit a relatively small percentage of the population to veto constitutional reform. As Oran Doyle observes in his chapter, 'The Justification of Constraints on Constitutional Amendment Powers' (Chapter ?), constitutional devices that place a polity's democratic structure beyond the reach of contemporary democratic majorities are, democratically, deeply suspect. This did not, however, appear to concern the British Government at the time. As the report on the termination of association of Dominica made clear, the British Government was perfectly aware that the possibility of any government being able to secure a two-thirds majority in a referendum on constitutional reform was vanishingly remote. The inclusion of such a requirement was thus clearly intended to place the system of government inherited upon independence beyond the reach of a future democratic majority of the citizens of these islands, thereby guaranteeing the preservation of the Westminster model whatever happened in the postindependence era.

44 S Tierney, Constitutional Referendums: The Theory and Practice of Republican Deliberation (Oxford: Oxford University Press, 2014) 271.

45 Mawby, n42 above at 215-231.

46 s.38 St Vincent and the Grenadines Constitution, s.39 Grenada Constitution; and s.47

Constitution Antigua and Barbuda. 


\section{PART II POST-INDEPENDENCE CONSTITUTIONAL REFORM AND AMENDMENT CULTURE}

In this section I wish, firstly, to examine the impact of the two main categories of formal amendment rules - special legislative majorities and referendum requirements - upon post-independence constitutional reform. I will then before proceed to explore the interaction of these amendment rules with the region's amendment culture.

\section{Special Legislative Majorities}

It is an indisputable fact that where constitutional reform has occurred in the region, with the exception of Guyana's 'socialist' Constitution of 1980 (which is discussed in more detail below), it has occurred where there has been no referendum requirement to satisfy. It is no coincidence, therefore, that two of the most constitutionally active countries in the region have been Trinidad and Tobago and Belize, both of which have constitutions that do not include a referendum requirement. Trinidad and Tobago was thus able in 1976 to move from a constitutional monarchy to a republic by means of a two-thirds legislative majority. This was no obstacle to Eric Williams and his Peoples National Movement, which had led the country into independence, and which had consistently won at least two-thirds of the available seats in parliament in each of the post-independence elections up until 1986. In Belize there were no less than eight amendments to the Constitution in the decade between 2001 and 2011.47 Again this was possible because in each of the general elections from 1998 up until 2008 the winning party had won over three-quarters of the available seats in parliament and was, therefore, comfortably able to satisfy the special legislative majorities required by s.69 to amend the Constitution.

It is also no coincidence that in the case of two of the other most constitutionally active countries - Guyana and Jamaica - the amendments which have been

47 GP Smith, 'Constitutionalism in Belize: Lessons for the Commonwealth Caribbean', University West Indies, Faculty Workshop Series 2008-9, 2008. Unpublished. On file with the author. 
enacted have been to those provisions in each Constitution which were not subject to a referendum requirement. Thus, in 1970, Guyana was able to replace the Queen as head of state with a ceremonial President by a simple legislative majority because express provision had been made for such an amendment in the independence Constitution.48 In Jamaica too, the single most important constitutional reform that has taken place since independence - the replacement of the Bill of Rights included in its independence Constitution with a new Charter of Fundamental Rights and Freedoms - was possible because it could be implemented by means of a two-thirds majority of both Houses of Parliament and did not require approval in a referendum.

\section{Referendums}

There have, to date, been four constitutionally mandated referendums in the post-independence era: in Guyana, Nevis, the Bahamas, and St Vincent and the Grenadines. In this section I will first explore the local factors which were particular to each and how they contributed to the outcome before proceeding in the following section to discuss the wider amendment culture in the region and how this too contributed to the outcome. I will begin with what was, undoubtedly, the most controversial referendum to have taken place in the region since Jamaica voted to withdraw from the West Indies Federation in 1961, and that is Guyana's referendum in 1978, which paved the way for Guyana to become a 'socialist Republic'.

\section{A. Guyana}

In the period between independence and the establishment of a 'socialist' Constitution in 1980 there were a number of formal amendments to the Guyanese Constitution, none of which required a referendum to be held. For example, in 1970 the Queen was replaced as Head of State and the right of appeal to the JCPC was abolished.49 However, the constitutional reforms that could be

48 Article 73(5) Guyana Independence Constitution 1966.

49 Art 73(5) Guyana Independence Constitution 1966. 
achieved by means of a legislative majority alone were not enough to satisfy the Peoples National Congress (PNC), who argued that a wholesale reform of the 1966 Constitution was needed in order to achieve their political objective of transforming Guyana into a 'Socialist Cooperative Republic'. The first step towards achieving this objective was to introduce a Bill in the National Assembly to amend Article 73 of the Constitution, the effect of which would be to remove the referendum requirement for the constitutional reforms that the Government was contemplating. Thus, whilst the Bill to amend Article 73 would itself have to be ratified by a referendum, once the Bill had been enacted large parts of the Constitution could be amended by a two thirds majority of the National Assembly. Since the PNC had hijacked the administration of elections shortly after its victory in the 1968 elections, and had secured 37 out of the 53 available seats in the National Assembly at the elections in 1973, which were themselves widely believed to have been rigged, achieving such a legislative majority presented no obstacle to the PNC. This would mean that in future the PNC would be able to amend large parts of the Constitution at their will.

The referendum that preceded the amendment of Article 73 of the Constitution has been described by Lutchman as 'one of the bitterest political and constitutional controversies in the history of Guyana'.50 It also confirms Tierney's observation that the egregious manipulation of referendums tends to occur most often in countries where there is already an established pattern of electoral misconduct.51

During the campaign the Government conducted an 'extensive and aggressive propaganda exercise'.52 This was made possible because, post-independence, the PNC had promulgated the idea that all institutions under public control, such as the media, should be mobilised in support of the socialist cause as embodied by the PNC.53 Opposition groups were not allowed to place advertisements in the state-owned media and pressure was brought to bear on those sections of the

50 RW James and HA Lutchman, Law and the Political Environment in Guyana (Institute of Development Studies, University of Guyana; Guyana; 1984) 61

51 Tierney n52 above at 102 .

52 James and Lutchman n61 above at 64

53Ibid, 65. 
media that were not under direct governmental ownership; for example, cutting off the supply of newsprint or the termination of advertising contracts with the Government.54 Those who were opposed to the Government's plans to amend Article 73 experienced difficulty in securing permission to hold their meetings. Even where permission was granted the meetings were disrupted by PNC supporters in the presence of police officers who did not seek to intervene.55 The collective actions of the Government resulted in a decision by opposition groups to boycott the referendum altogether and the Government, unsurprisingly, succeeded in winning an outright majority in the referendum.

Contrary to the PNC's claims that a majority of the registered voters had taken part in the referendum and had overwhelmingly voted to approve the amendment of Article 73, Lutchman argues that the results of the referendum 'must rank as among the most corrupt results ever in an election type exercise'.56 Certainly, there was widespread suspicion about the results, based on the fact that a 'derisively minuscule' proportion of the population had actually voted in the referendum.57 In protest, opposition groups refused to take part in the Constituent Assembly that was subsequently established by the Government and charged with the task of drafting the new Constitution. The result was that the draft Constitution that was approved by the Constituent Assembly was substantially the same in form and substance as the draft that had been submitted to the Constituent Assembly by the PNC.58

In the subsequent elections in 1980, which should have taken place in 1978, but were postponed to allow the referendum to take place, the PNC increased its majority still further, winning 41 out of the 53 sets in the National Assembly.

\section{B. Nevis}

St Kitts and Nevis, which achieved independence in 1983, is the world's smallest federation. Though the two islands had first been linked when a party of British

54Ibid, 70.

55 Ibid

56Ibid, 71 .

57lbid.

58Ibid, 75 . 
colonists from St Kitts landed on Nevis in 1628, political relations between the islands have been tense ever since the British government decided in 1882 to unite the islands (together with the island of Anguilla) into one administrative unit. This tension is reflected in s.113 of the independence Constitution, which expressly provides for Nevis to secede from the federation if this is approved by a two-thirds majority of all the members of the Nevis Assembly and two-thirds of Nevisians in a referendum.

For the first decade of independence the secession issue remained latent. However, it resurfaced in 1996. The catalyst on this occasion was the federal government's plans to regulate offshore financial services within the federation.59 The Nevis administration contended that the federal government's real objective was to place the financial and business sectors of Nevis under its control and direction, the effect of which would have been to undermine the constitutional and legislative authority of Nevis at the same time as destroying its economy.60 The Concerned Citizens Movement (CCM), having won a majority in the 1997 elections to the Nevis Assembly in which the CCM had pledged to hold a referendum on secession, the Premier of Nevis, Vance Amory, immediately invoked s.113 of the Constitution and tabled a Separation Bill. The Bill was approved by all five members of the Nevis Assembly, and thus easily satisfied the two-thirds majority required by the Constitution. However, in the subsequent referendum, which was held on $10^{\text {th }}$ August 1998, 'unaccountably and to the surprise of nearly all observers', the requisite two-thirds of the electorate did not vote in favour of secession. On what was a relatively low turnout only $61.7 \%$ of those who took part in the referendum voted in favour of secession.61

Two possible reasons for the Government's failure to win the necessary twothirds majority in the referendum have been suggested. The first was the lobbying of the electorate by political leaders elsewhere in the region who were haunted by the spectre of secession in their own multi-island states: for example,

59 Sir Fred Phillips n8 above at 137.

60 Ibid.

61 D Midgett, 'Pepper and bones: the secessionist impulse in Nevis' New West Indian Guide 78

(2004). No.1/2, Leiden, 43-71, at 61 
Antigua and Barbuda and Trinidad and Tobago. The second, according to Midgett, was the absence of a meaningful political movement that could realise the goal of secession.62 Nevisians may have been ardent separatists but, in the final analysis, an insufficient number of Nevisians were 'willing to take the political step of re-creating themselves as a nation-state.'63

\section{The Bahamas}

The Constitution of the Bahamas has remained virtually unaltered in the 40 odd years of its existence. Prior to 2002 there had been some minor constitutional amendments, such as changing the definition of the financial year, none of which required a referendum. However, amending the Constitution in this way is very much the exception to the rule, since 104 of the 137 Articles of the Constitution require approval in a referendum before they can be amended.64 Accordingly, in 2002, when the Government wished to make a number of reforms to the Constitution, having achieved the necessary two-thirds majorities in both Houses of Parliament, it still needed to obtain majority approval in a referendum.

The reforms that were proposed included: the removal of discriminatory provisions relating to women under the citizenship section; the inclusion of gender as a prohibited ground of discrimination; the establishment of a Parliamentary Commissioner; the transfer of the Attorney General's powers relating to criminal proceedings to a newly established Director of Public Prosecutions; putting the Teaching Services Commission on an equal footing with other Public Service Commissions; the establishment of a Boundaries Commission to carry out the functions previously exercised by the Constituencies Review Commission; and an extension of the retirement age for senior judges. Though progressive, these reforms were, essentially, very modest, leaving the basic structure of government virtually unchanged. Nevertheless, the

62 Ibid at 67.

63 Ibid.

64 Report of Constitutional Review Commission of the Bahamas 2013, paragraph 12.1. Available at < http://www.bahamas.gov.bs/wps/wcm/connect/7c2fe440-cb66-4327-9bf3-

432131510cc4/Constitution+Commission+Report+2013_8JULY2013.pdf?MOD=AJPERES > 
Government still failed to secure the approval of a majority of the voters in the referendum.

The Constitutional Review Commission, which reported in 2013, suggested that there were a number of interlocking reasons why the government failed to win popular approval for its package of reforms. These included: the contamination of the referendum by other political controversies; the imminence of a general election; ambivalent feelings about the gender-equality aspects of the citizenrelated proposals; the complexity of the Constitutional Amendment Bills; and, lastly, a lack of public education about the proposed amendments.65

\section{St Vincent and the Grenadines}

St Vincent and the Grenadine's 2009 referendum on constitutional reform offers the perfect antithesis to Guyana's 1978 referendum, both in terms of its legitimacy and in terms of the efforts that were made by the Government to engage civil society in the reform process. This process began in 2003 with the honouring of a manifesto commitment by the United Labour Party to establish, on a statutory basis, a Constitution Review Commission (CRC), which was charged with consulting widely before making recommendations for the reform of the Constitution. The CRC was composed of 25 people from a cross-section of the political, social and legal community (including the diaspora). The process of consultation was thorough, with various publications being produced along the way, outlining the options available and summarising the level of progress achieved. There was also a significant effort to encourage input from across Vincentian society and the wider diaspora.66

The CRC's report was published in 2005, and again in revised form in 2006. It was comprehensive and recommended a number of major reforms to the country's Constitution. These included: the removal of the British monarch as head of state and her replacement with a ceremonial president; an increase in the number of elected members of the National Assembly from 15 to 17; the

\footnotetext{
65 Ibid, paragraph 8.4

66 The following account of the referendum is drawn from ML Bishop, 'Slaying the

"Westmonster" in the Caribbean? Constitutional Reform in St Vincent and the Grenadines' (2011)

13 British Journal of Politics and International Relations 420-37.
} 
addition of seven 'civil society' senators; limiting the Prime Minister to two terms in office and reducing his role in bureaucratic appointments; capping the number of ministers to 13 to ensure that the cabinet does not have a majority in the legislature; and establishing a National Advisory Council of Elders (NACE) which would provide 'the conscience of the nation.'

Once the draft Constitution had been finalised 15,000 copies were printed and distributed cheaply to ensure that most people in the country - of approximately 30,000 households - would have access to it. In addition there were numerous town hall meetings where the Drafting Committee, along with members of the Constitutional Reform Steering Committee - a slimmed-down version of the CRC - and Government, discussed the process with the wider population. These meetings were broadcast live on national radio, continuing the pattern of television and radio coverage that had accompanied many of the parliamentary debates on the subject. All of this public deliberation and consultation was not enough, however, to persuade a sufficient majority of the electorate (two thirds) of the need for constitutional reform, and the Constitutional Reform Bill was, ultimately, rejected by 55 per cent of voters in the referendum.

Bishop has suggested a number of reasons for the Government's failure to win the referendum, such as the length of the draft Constitution, which was a massive tome, running to 160 pages, 'with endless clauses and clarifications used to codify the myriad new institutions', unlikely to enthuse a population that had already been subjected to six years of public debate about constitutional reform. 67 Bishop also points out that the draft Constitution was very much a watereddown version of the much more radical reforms recommended by the CRC. There was no limit on the number of terms of office that a Prime Minister could serve, there was no room for the seven civil society's senators, and no place for NACE. Ultimately, while the draft Constitution included some significant reforms it was not sufficiently 'uplifting' to transcend party politics.68

The Prime Minister of St Vincent, Ralph Gonsalves, while apportioning much of the blame for the failure of his government's efforts to implement constitutional

67 n77 above.

68 Ibid. 
reform, was also highly critical of the two-thirds referendum requirement in his country's independence Constitution. According to Prime Minister Gonsalves, this was a relic of colonialism that had been introduced by the British Government 'to counter the type of authoritarianism that had been the hallmark of Eric Gairy in Grenada' and 'to neuter radical approaches to governance in the early post-independence era.'69 Indeed, at a recent conference in Jamaica, Prime Minister Gonsalves revealed that he never realistically expected that his government would succeed in achieving a two-thirds majority in the referendum. Nevertheless, he pressed ahead with the referendum, hoping that it would be possible to secure a simple majority vote. This, he believed, would have provided him with a sufficient democratic mandate to invoke the constituent power by inviting the British Government to amend St Vincent's Independence Constitution in the same way that it had been created, i.e. by an Order-in-Council of Her Majesty.70

\section{Amendment culture}

It is clear that there is a degree of correlation between constitutional design and constitutional amendment as measured by reference to the frequency of constitutional amendment in those countries where the only requirement is a special legislative majority and those countries where, in addition to a special legislative majority, a majority of voters in a referendum is required. It is also clear, however, that, viewed in the round, the formal amendment rules have not served to fulfil the function envisaged by Elkins et al of promoting flexibility by allowing these constitutions to adapt to meet changing political, social and economic circumstances. More often than not, they have simply preserved the status quo ante, thereby fulfilling the role intended for them by the region's political leaders at the time of independence and by the British Government.

\footnotetext{
${ }_{69}$ On Constitutional Reform in St Vincent and the Grenadines, Statement to Parliament May 28, 2009. Available at <http://www.star983fm.com/PMconstit.pdf>

70 Note on file with the author.
} 
This does not, however, answer the underlying question of why so many governments have been unable to satisfy the amendment requirements of their constitutions. In the case of those countries with very onerous referendum requirements, it is possible to argue that a two thirds majority represented an impossibly high threshold for any Government to satisfy, as demonstrated by the failure of the Government of Nevis to persuade a two thirds majority of its citizens to vote for secession. However, in the case of St Vincent and the Grenadines, the Government was unable to persuade even a simple majority of its citizens to vote for its package of reforms. The Government was, therefore, in no different position to the Government of the Bahamas, which also failed to persuade a simple majority of its citizens to vote for what were essentially very modest constitutional reforms. There were, of course, as we have seen in both cases, local factors at play. However, the lack of political consensus generally around constitutional reform and the inability of governments even to obtain a simple majority in a referendum process which they, effectively, control points to the existence of a wider amendment culture in the region, which transcends the institutional obstacles presented by formal amendment rules, and which exists 'independently of the substantive issue under consideration,'71 But what factors have contributed to the emergence of such a culture in the region?

One factor, which has been mentioned by scholars, such as Sutton, is the deeply conservative nature of the political culture of the region, which derives in part from the small size of almost all of the countries in the region (small states tending to be quite conservative), but also from the history of slavery and assimilation in the region.72 As Sutton explains, as 'free people of colour' emerged as elements of a middle class in the years following the abolition of slavery their value system was shaped by the metropolitan connection and the colonial elite who represented it in the individual colony. 73This was further buttressed by the brief tutelage of the region's political leaders in the operation of the so-called Westminster model of government in the decade or so leading up

\footnotetext{
71 Ginsburg and Melton $\mathrm{n} 15$ above at 12.

72 Sutton, n? above at 69.

73 Ibid.
} 
to independence.74 This meant that by the time of independence local political leaders were very well versed in the system of government embodied in their independence constitutions. As Norman Manley, the Premier of Jamaica at the time its independence Constitution was being negotiated, explained:

I make no apology for the fact that we did not attempt to embark upon any original or novel exercise for constitution-building. We had a system which we understood; we had been operating it for many years with sense. It's a system which has endured in other countries for generations successfully. It is a system which is consistent with the sort of ideals we have in this country, and it was not difficult to decide that we would follow that familiar system with those modifications which we thought the circumstances of Independence deserved.

Within the region there was not, therefore, the sense of a lack of autochthony which Wheare had predicted would compel these newly independent countries very quickly to replace their constitutions with something 'homegrown'. There was not the appetite for constitutional amendment which existed in Britain's former colonies in Africa, such as Ghana and Tanzania. Instead, there was a popular attachment to the text of these constitutions which has not only survived independence, but which appears actually to have grown in the intervening period.

A second factor is the political tribalism and adversarialism, which has become so engrained in the region's political culture as a result of the 'winner takes all' nature of the 'first past the post electoral system', which is the electoral system of choice across the region. 75 Where constitutional reform has taken place, as in Trinidad and Tobago and in Belize, it has occurred during a period when the government has had a sufficiently large legislative majority that it has been able to press ahead with reform without the need for the support of the opposition. Absent an in-built majority, governments have found it almost impossible to

74 JI Dominguez, 'The Caribbean Question: Why has Liberal Democracy (Surprisingly Flourished? In JI Dominguez et al (eds), Democracy in the Caribbean (Baltimore: John Hopkins University Press, 1993) 57.

75 With the exception of Guyana where a party list proportional representation system is deployed. See D O'Brien $\mathrm{n} 8$ above at 73. 
build a political consensus around constitutional reform. In Jamaica, for example, it proved impossible for the People's National Party when in power to garner the requisite two-thirds legislative majority to amend the Constitution in order to replace the Judicial Committee of the Privy Council (JCPC) with the Caribbean Court of Justice (CCJ) as the country's final appellate court, even though the amendment enjoyed considerable popular support.76 In Trinidad and Tobago too, an attempt by the Government in 2011 to amend the Constitution to preclude constitutional challenge to the implementation of the death penalty by prisoners based on the grounds of delay or inhuman or degrading prison conditions failed because the Government was unable to achieve the 31 votes in the House of Representatives that were needed to amend the Constitution, even though the death penalty is extremely popular with voters in Trinidad and Tobago.77 While it is true that in Jamaica the Government was able to build the necessary political consensus to achieve the two thirds majority of both Houses of Parliament required to replace its Bill of Rights with a new Charter of Fundamental Rights and Freedoms, it took nearly two decades, and a number of compromises with regard to the contents of the Charter, in order to achieve this consensus.78

Bishop also notes that the failure of the Government of St Vincent and Grenadines to win even a nominal majority in the referendum on constitutional referendum was in no small part due to the fact that the bipartisanship, which had accompanied the creation of the CRC and which had been maintained for the first few years of public consultation, had completely dissipated by 2007, with the opposition New Democratic Party withdrawing from the entire process.79 Here, as elsehere in the region, the levels of political tribalism and adversarialism generated by a 'winner takes all' culture created an environment of distrust which was not conducive to consensus-building around constitutional reform. As Contiades and Fotiadou argue in Chapter (?), 'Amendment-Metrics:

\footnotetext{
76 D O'Brien, 'The Caribbean Court of Justice and its Appellate Jurisdiction: A Difficult Birth [2006] Public Law 344-363

77 Constitution (Amendment) Capital Offences) Bill 2011

78 See D O'Brien and S Wheatle, Post-Independence Constitutional Reform in the Commonwealth Caribbean and a New Charter of Fundamental Rights and Freedoms for Jamaica, [2012] Public Law, 683-702.

79 Bishop n? above.
} 
The Good, the Bad, and Frequently Amended Constitution', a culture of distrust exerts an immense influence on the way that the mechanisms of constitutional amendment operate.

A third factor which has contributed to amendment culture in a number of countries is the institutional structure surrounding the amendment process. As Ginsburg and Melton have argued, it is possible that a low threshold for amending the constitution can lead to the exercise of caution when constitutional reform is being proposed precisely because it is too easy. 80 Evidence of just such a phenomenon can be found in the emergence of an implied referendum requirement amongst those countries in the region with constitutions that do include an express referendum requirement: Barbados, Belize, and Trinidad and Tobago.

In Barbados, for example, following the recommendation of the Forde Commission, in 1998, that Barbados should become a parliamentary republic, with a President replacing the Queen as Head of State,81 it would have been perfectly possible for the Government to have acted upon this proposal and to have amended the Constitution by means of a two-thirds majority in both Houses of Parliament. In both the 1999 and 2003 elections the Barbados Labour Party had won with large majorities. These translated into 26 of the 28 seats available in the 1999 elections and 25 out of the out of the 28 seats available in the 2003 elections. Notwithstanding its overwhelming electoral mandate, the Government decided, however, that such a fundamental constitutional reform needed to be put to the vote of the people in a referendum. A Referendum Bill was, accordingly, introduced in parliament in 2000, but for various reasons was not enacted until 2005. Though the Referendum Act 2005 did not itself fix a date for the referendum to be held, the Government decided that to save costs it should coincide with the date of the next general election in 2008. In the event, however, the referendum was not held in 2008 and has been deferred by successive governments ever since.

80 Ginsburg and Melton above n.15 at 14.

81 Report of the Constitution Review Commission Barbados 1998. Unpublished. On file with author. 
In Trinidad and Tobago too it would be perfectly possible, from a strictly legal perspective, to amend the Constitution by means of a two-thirds legislative majority in order to abolish the right of appeal to the JCPC and to replace it with a right of appeal to the CCJ.82 However, the Prime Minister, Kamla Persad Bissessar, has recently announced that before any such amendment can take place it will have to be approved by the people in a referendum, in accordance with the recommendation of the 2013 Report of the Constitution Reform Commission (CRC).83 Though it is true that because of the strained relationship between the Government and the Opposition it would have been difficult for the Government to achieve the two-thirds legislative majority necessary to implement this amendment, the acceptance by the Prime Minister of the need for a referendum, where none is required by the Constitution, still represents a remarkable acknowledgment of implied constraints on the amending power of the constitutional legislator. The CRC has even gone one stage further by recommending that not only this reform, but also a host of other constitutional reforms which it was recommending, should only be introduced following majority approval in a referendum, though this is not strictly required by the Constitution.84

Finally, in Belize, which has been one of the most constitutionally active countries in the post-independence era the Government eventually came unstuck in its efforts to reform the Constitution in 2008 when attempting to introduce legislation to remove the protection afforded by section $17(1)$ of the Constitution to the owners of:

[P]etroleum minerals and accompanying substances, in whatever physical state located on or under the territory of Belize ... the entire property and control over which are exclusively vested, and shall be deemed always to have been so vested, in the Government of Belize. 85

\footnotetext{
82 S.54 Constitution Trinidad and Tobago.

83 Report Trinidad and Tobago Constitution Reform Commission December 27, 2013, paragraph 277. Available at < http://www.reformtheconstitution.com/wpcontent/uploads/2014/01/TTCRC-Report-Web.pdf> 84 Ibid, paragraph 33.

85 Belize Constitution (Sixth Amendment) Bill 2008.
} 
In proceedings brought by a group of disgruntled landowners, Bowen v Attorney General,86 the proposed amendment was struck down, even though it had been approved by the special three-quarters majority required by s.69 of the Constitution, on the ground that it offended the 'basic structure' of the Constitution. According to the Chief Justice Conteh, s.69 was no more than a 'procedural handbook', whereas the Constitution is 'the embodiment and immanation of the people of Belize as a whole: it is their constitution.' 87 It followed, therefore, that a fundamental reform of the Constitution, such as the disapplication of the fundamental rights guarantee contained in section 17(1), could only be achieved by means of a referendum, even if this was not expressly required by the Constitution. Following the judgment in Bowen, the Government tried for a second time to amend s.17 of the Constitution by simultaneously amending s.69 of the Constitution to provide that once a Bill had received the approval of the special legislative majority required by the Constitution the constitutionality of the Bill could not be reviewed by the courts. Once again, however, the Government's attempt to effect such a fundamental reform of the Constitution without securing the approval of the people in a referendum was struck down by the Supreme Court.88

In all three countries then a norm is clearly emerging at the political/judicial level, which regards fundamental constitutional reform that has not been mandated by the majority of citizens in a referendum as democratically unacceptable, even if it appears to be permitted by the constitutional text. The emergence of such a norm points to a special political weight being accorded to the value of entrenchment in these countries and to an amendment culture which is responsive to the constitution's institutional structure.

\section{Conclusion}

86 BZ 2009 SC 2. Unreported. Available at <www.belizelaw.org>.

87 This was because the Belize Act 1981 passed by the UK Parliament expressly recognised Belize's self-governing status and the right of the Belizean Parliament to amend the Order-inCouncil issued by Her majesty, which it did in September 1981.

88 British Caribbean Bank Ltd v Attorney General Belize, Claim No. 597 of 2011. Unreported. Available at <www.belizelaw.org $>$. 
As our survey of constitutional reform in the region indicates, there is only very limited evidence to support the theory that formal amendment rules contribute to constitutional endurance by allowing constitutions to be amended rather than being replaced in their entirety. As we have seen, there has been very little amendment of the region's constitutions in the post-independence era. Indeed, there is plentiful evidence that in a number of cases the formal amendment rules included in the region's constitutions have instead acted as a barrier to constitutional amendment. This is especially true of those countries with constitutions which include a referendum requirement. As we have seen, only one government, the PNC in Guyana, has so far succeeded in obtaining the support of the requisite majority of its electors in a referendum for its constitutional reform programme, and it is widely suspected that the PNC only managed to achieve this by manipulating all aspects of the referendum process. To this extent, at least, they have functioned in exactly the way they were designed to function by the region's political leaders at the time of independence and by the British Government.

It is thus with some justification that the Prime Minister of St Vincent and the Grenadines has complained that the very onerous referendum requirements included in his country's Constitution were 'a colonial anachronism', obliging him to consider taking the extraordinary step of inviting the former colonial ruler, retrospectively, to amend his country's Constitution. To paraphrase Joshua Braver in his Chapter (?), 'Hannah Arendt in Venezuela: The Supreme Court Battles Hugo Chavez Over the Creation of the 1999 Constitution', the citizens of these countries were born into a constitutional history and narrative that was not of their choosing and from which it is nearly impossible for them to break free.

It would be wrong, however, to conclude that referendum requirements are the only reason for the glacial pace of constitutional reform in the region. As we have seen, regard must also be had to the amendment culture abroad in the region, which is indicative of an underlying level of resistance to constitutional reform. This suggests an attachment to the text of the region's independence constitutions that defies the predictions of scholars that they would soon be 
replaced after independence and is in marked contrast to the lack of attachment to their founding texts manifested by the citizens of Britain's former colonies in Africa, in countries such as Tanzania and Ghana, which replaced their constitutions very shortly after independence. There are a number of factors that have contributed to the emergence of such a culture, including the experience of colonial rule in the Commonwealth Caribbean, which included an extended period of self-government prior to independence, and a degree of political tribalism which is inimical to building a consensus around constitutional reform. There is also the emergence of a norm in response to the threat of constitutional amendment by special legislative majority in those countries with constitutions that do not include a referendum requirement, which insists that fundamental constitutional reform demands the legitimacy that can only be conferred by a referendum

It is impossible to quantify with any degree of exactitude the strength of the amendment culture within a single country, let alone across an entire region. However, we should soon have a better appreciation of the strength of the region's amendment culture as three constitutional referendums are scheduled to take place in the region within the next year: in Grenada, St Lucia and the Bahamas. In each case the referendum has been preceded by a Constitutional Review Commission, which has consulted widely and deliberated at length.89 A failure by the government to obtain a majority in any of these referendums could only add weight to the impression that, regardless of the substance of the amendments being proposed, there is a pervasive amendment culture at work across the region which is resistant to constitutional reform.

89 See, for example, description of the consultation process outlined in the Report of St Lucia Constitutional Reform Commission, March 2011, 1-18. Unpublished. On file with author. 